Article

\title{
Anti-Biofilm and Anti-Hemolysis Activities of 10-Hydroxy-2-decenoic Acid against Staphylococcus aureus
}

\author{
Kuankuan Gao ${ }^{1,2, \dagger}$, Bei Su ${ }^{1,2, \dagger}$, Jing Dai ${ }^{2}$, Piwu Li ${ }^{1,2}$, Ruiming Wang ${ }^{1,2}$ and Xiaohui Yang ${ }^{1,2, *(D)}$ \\ 1 State Key Laboratory of Biobased Material and Green Papermaking (LBMP), Qilu University of \\ Technology (Shandong Academy of Sciences), Jinan 250353, China; 13969083326@163.com (K.G.); \\ subei970211@163.com (B.S.); piwuli@126.com (P.L.); ruiming3k@163.com (R.W.) \\ 2 Key Laboratory of Shandong Microbial Engineering, Qilu University of Technology (Shandong Academy of \\ Sciences), Jinan 250353, China; jingdai_flower@sina.com \\ * Correspondence: xiaohuiyang@qlu.edu.cn or yangxh919@126.com \\ + These authors contributed equally to this work.
}

check for updates

Citation: Gao, K.; Su, B.; Dai, J.; Li, P.; Wang, R.; Yang, X. Anti-Biofilm and Anti-Hemolysis Activities of 10-Hydroxy-2-decenoic Acid against Staphylococcus aureus. Molecules 2022, 27, 1485. https://doi.org/10.3390/ molecules 27051485

Academic Editors: Gerson Nakazato, Renata Katsuko Takayama Kobayashi and Anake Kijjoa

Received: 28 January 2022

Accepted: 18 February 2022

Published: 22 February 2022

Publisher's Note: MDPI stays neutral with regard to jurisdictional claims in published maps and institutional affiliations.

Copyright: (C) 2022 by the authors. Licensee MDPI, Basel, Switzerland. This article is an open access article distributed under the terms and conditions of the Creative Commons Attribution (CC BY) license (https:// creativecommons.org/licenses/by/ $4.0 /)$.

\begin{abstract}
Persistent infections caused by Staphylococcus aureus biofilms pose a major threat to global public health. 10-Hydroxy-2-decenoic acid (10-HDA), a main fatty acid in royal jelly, has been shown to possess various biological activities. The purpose of this study was to explore the effects of 10-HDA on the biofilms and virulence of S. aureus and its potential molecular mechanism. Quantitative crystal violet staining indicated that 10-HDA significantly reduced the biofilm biomass at sub-minimum inhibitory concentration (MIC) levels (1/32MIC to 1/2MIC). Scanning electron microscope (SEM) observations demonstrated that 10-HDA inhibited the secretion of extracellular polymeric substances, decreased bacterial adhesion and aggregation, and disrupted biofilm architecture. Moreover, 10-HDA could significantly decrease the biofilm viability and effectively eradicated the mature biofilms. It was also found that the hemolytic activity of $S$. aureus was significantly inhibited by 10-HDA. qRT-PCR analyses revealed that the expressions of global regulators sar $A$, agr $A$, and $\alpha$-hemolysin gene hla were downregulated by 10-HDA. These results indicate that 10-HDA could be used as a potential natural antimicrobial agent to control the biofilm formation and virulence of S. aureus.
\end{abstract}

Keywords: 10-hydroxy-2-decenoic acid; Staphylococcus aureus; biofilm; hemolytic activity

\section{Introduction}

Staphylococcus aureus is a pathogenic microorganism responsible for a variety of infectious diseases in humans, ranging from skin infection to severe tissue infection and bacteremia [1,2]. It is also one of the foodborne pathogens that causes food contamination and food poisoning [3,4]. Planktonic $S$. aureus has a strong ability to form biofilms on the surfaces of medical devices and food equipment [5-7]. Biofilms are complex microbial ecosystems formed by bacterial communities embedded in a self-produced matrix of extracellular polymeric substances (EPS), which increase bacterial resistance to antimicrobial agents and extreme environments, and promote cross-contamination [8-10]. Thus, the bacteria in biofilms are more difficult to eradicate. In addition, S. aureus can produce several virulence factors, such as hemolysin, enterotoxin, and coagulase, which are associated with the pathogenicity of $S$. aureus [11]. In particular, $\alpha$-hemolysin is an important virulence factor involved in the pathogeneses of skin infections, pneumonia, and sepsis [12]. In the past few years, numerous antibiotics and disinfectants have been used to combat pathogens. However, the long-term use of antibiotics and synthetic chemicals leads to the emergence of resistance, high toxicity, and other negative effects on human health and the environment $[13,14]$. Therefore, it is necessary to explore novel and safe antibacterial agents. Currently, natural products are considered to be an important source of "eco-friendly" antimicrobials [14]. Natural products from plants, animals, and microorganisms have been widely discovered, providing attractive candidates for the development of antibacterial agents [15-18]. 
10-Hydroxy-2-decenoic acid (10-HDA), also known as royal jelly acid, is the major fatty acid component of royal jelly. 10-HDA has been reported to possess a variety of activities beneficial to human health, including anti-inflammatory [19,20], antitumor [21-23], immunomodulatory [24,25], and lifespan-extending activities [26]. We have previously reported that 10-HDA has an antibacterial activity against planktonic S. aureus by destroying the integrity of the cell membrane [27]. However, the inhibition effects of 10-HDA on S. aureus biofilms and virulence production remain unclear. Thus, the effects of 10-HDA on biofilm formation and the mature biofilms of $S$. aureus were investigated in this study by detecting the biomass, morphology, cell viability, and extracellular polymeric substances (EPS) production of biofilms. The effect of 10-HDA on the hemolytic activity of S. aureus was also evaluated. Furthermore, the molecular mechanisms of the 10-HDA-mediated inhibition of biofilm formation and virulence production were explored through qRT-PCR analysis.

\section{Results and Discussion}

\subsection{Effect of 10-HDA on the Growth of Planktonic Bacteria and Biofilm Biomass}

The minimum inhibitory concentration (MIC) of 10-HDA against S. aureus ATCC25923 was $2.25 \mathrm{mg} / \mathrm{mL}$. The influence of 10-HDA at sub-MIC levels on the planktonic growth and biofilm formation of S. aureus is shown in Figure 1. The planktonic growth of S. aureus was not significantly inhibited after 10-HDA treatment at concentrations ranging from 1/32MIC $(0.07 \mathrm{mg} / \mathrm{mL})$ to $1 / 2 \mathrm{MIC}(1.13 \mathrm{mg} / \mathrm{mL})$. However, $10-$ HDA significantly reduced the biomass of $S$. aureus biofilms in a dose-dependent manner $(p<0.01)$. When treated with $10-\mathrm{HDA}$ at concentrations from $1 / 32 \mathrm{MIC}$ to $1 / 2 \mathrm{MIC}$, the biofilm biomass was reduced by $41.9 \%$ to $72.9 \%$. The results indicated that the inhibitory effect of 10 -HDA on $S$. aureus biofilm formation was attributed to the anti-biofilm ability of 10-HDA rather than the inhibition of the bacterial growth, and this feature may prevent the emergence of bacterial resistance [28].

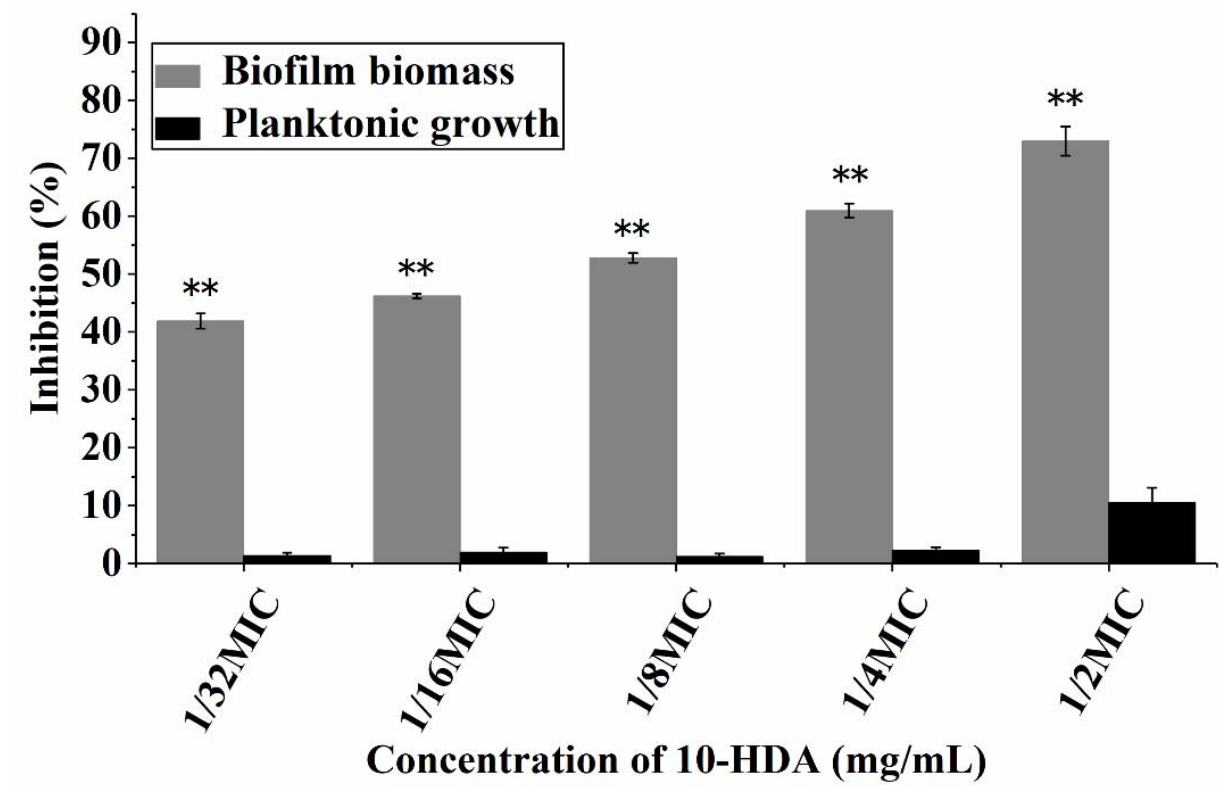

Figure 1. Effect of 10-HDA at sub-MIC levels on the planktonic growth and biofilm biomass of S. aureus. ${ }^{* *} p<0.01$.

\subsection{Effect of 10-HDA on the Morphology of S. aureus Biofilms}

The morphological and microstructural changes in $S$. aureus biofilms treated with 10-HDA were observed by SEM (Figure 2). The biofilms without 10-HDA treatment were densely packed with bacteria, and the bacteria were enveloped in the EPS structure of the biofilm. In contrast, after 10-HDA treatment at $1 / 4 \mathrm{MIC}$ and $1 / 2 \mathrm{MIC}$, the EPS structure almost disappeared in the microscopic field, and the biofilms exhibited fewer cells that were loosely attached to the glass slides. In order to form biofilms, bacteria produce 
EPS to mediate their adhesion to inert surfaces and promote their survival in extreme environments $[9,29]$. In this study, SEM observations demonstrated that 10-HDA inhibited EPS production, decreased bacterial adhesion and aggregation, and disrupted biofilm architecture, which conferred the remarkable inhibition effect of 10-HDA on S. aureus biofilm formation.

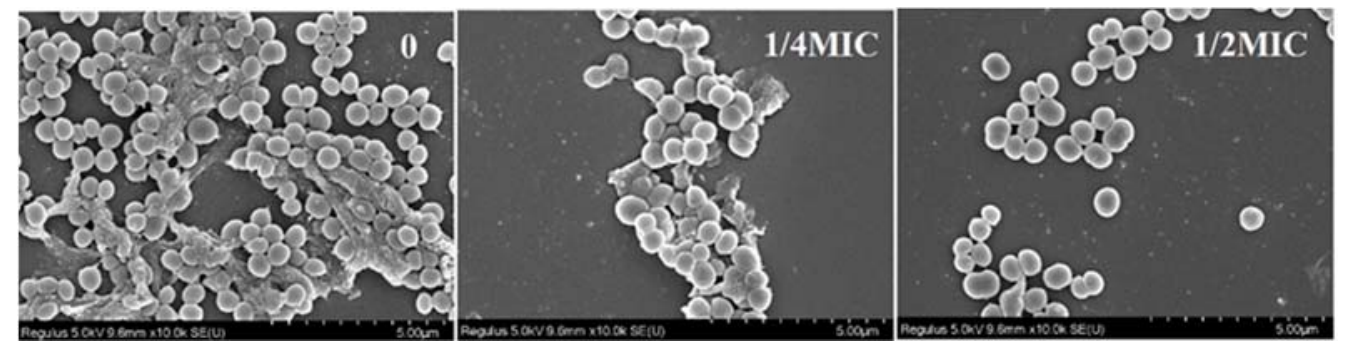

Figure 2. SEM images $(\times 10,000)$ of $S$. aureus biofilms with $10-$ HDA treatment at the indicated concentrations.

\subsection{Effect of 10-HDA on Cell Viability during Biofilm Formation}

The effect of 10-HDA on the metabolic activity of $S$. aureus biofilms was measured by MTT assay. As shown in Figure 3A, the metabolic activity of cells in the biofilms significantly decreased upon treatment with 10-HDA from 1/32MIC to 1/2MIC. After treatment with $1 / 2$ MIC of 10-HDA, the metabolic activity of the biofilm cells decreased by $73.6 \%$.

A

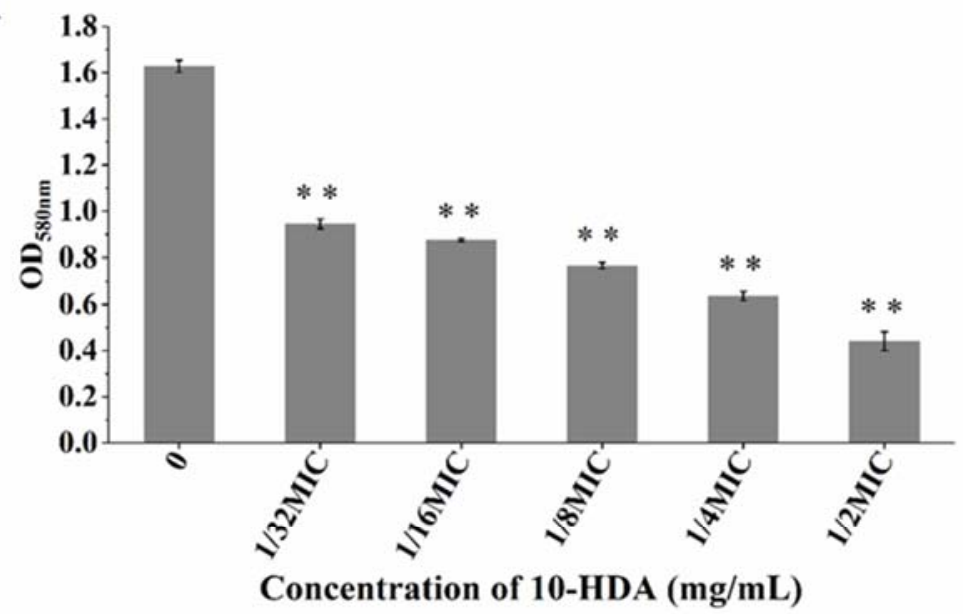

B

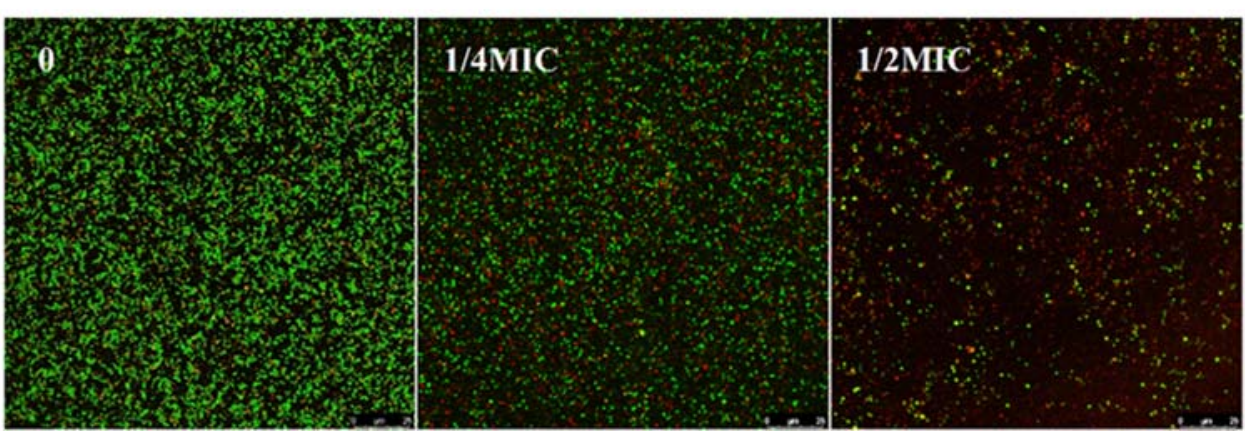

Figure 3. Effect of 10-HDA on bacterial viability during biofilm formation. (A) Effect of 10-HDA on the metabolic activity of the cells in S. aureus biofilms, as analyzed by MTT assay. ${ }^{* *} p<0.01$. (B) CLSM images of $S$. aureus biofilms. Green fluorescence: live cells; red fluorescence: dead cells. 
Moreover, the effect of 10-HDA on bacterial viability during biofilm formation was investigated by Confocal Laser Scanning Microscopy (CLSM). SYTO 9 dye can stain live bacteria with intact membranes and fluoresce green, whereas PI dye can stain dead bacteria with damaged membranes and fluoresce red [30]. The CLSM images are shown in Figure 3B. The biofilms without 10-HDA treatment presented a dense green fluorescence, indicating that the bacteria were alive. Meanwhile, in the treatment with 10-HDA at 1/4MIC, the green fluorescence presented by the biofilms decreased obviously, and the red fluorescence increased compared with the control. After the treatment with 10-HDA reached 1/2MIC, most of the cells appeared red in the field of vision. These images, as well as the MTT results, indicate that 10-HDA had a significant inhibitory effect on the cell viability of S. aureus during biofilm formation. Similar observations were reported for other antibiofilm agents, such as gallic acid and shikimic acid, which inhibited biofilm formation and reduced the cellular viability of bacteria, suggesting that these agents might destroy the EPS structure and enter biofilms to inactivate the protected cells [31-33].

\subsection{Effect of 10-HDA on EPS Production}

EPS are biopolymers produced by bacteria, mainly composed of extracellular polysaccharides, proteins, and extracellular DNA (eDNA). They provide a stable architecture for biofilms to mediate bacterial adhesion and aggregation [9]. Thus, the destruction of EPS is also an important indicator for evaluating anti-biofilm activity. As shown in Figure $4 \mathrm{~A}-\mathrm{C}$, the contents of extracellular polysaccharides, proteins, and eDNA in the biofilms decreased significantly with the increase of the 10-HDA concentration. When the 10-HDA concentration was $1 / 2 \mathrm{MIC}$, the inhibition rate of extracellular polysaccharides, proteins, and eDNA reached $67.4 \%, 83.5 \%$, and $76.8 \%$, respectively. This result suggested that $10-\mathrm{HDA}$ could reduce EPS production to prevent the formation of biofilms, which was consistent with the results of the SEM images above.

$\mathbf{A}$

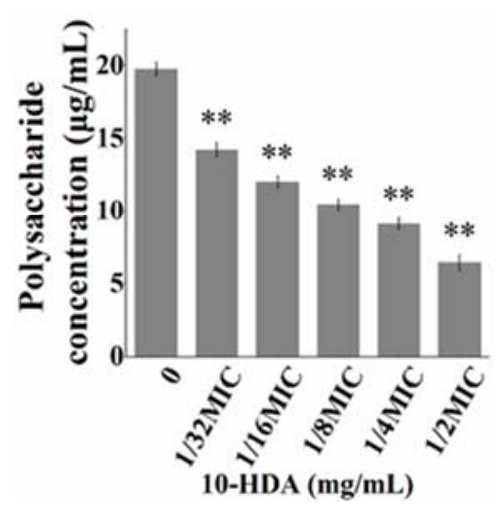

B

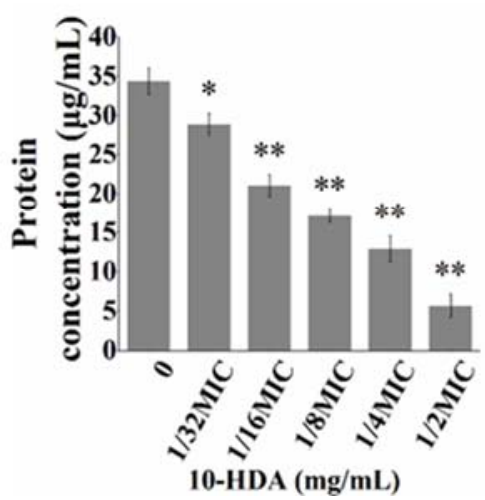

C

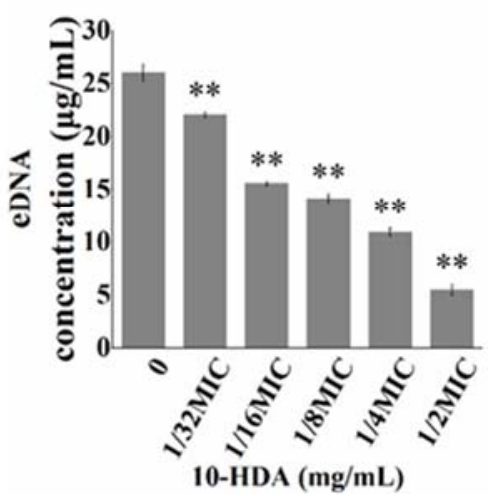

Figure 4. The contents of extracellular (A) polysaccharides, (B) proteins, and (C) eDNA in S. aureus biofilms after 10-HDA treatment. ${ }^{*} p<0.05,{ }^{* *} p<0.01$.

\subsection{Effect of 10-HDA on Mature Biofilms}

Mature biofilms are considered to be highly organized ecosystems with many water channels for material exchange [34]. Thus, mature biofilms possess a higher viability and are extremely difficult to eradicate. Our results showed that 10-HDA significantly reduced the biomass of mature biofilms at concentrations ranging from 1/32MIC to $1 / 2 \mathrm{MIC}$ $(p<0.01)$. When treated with 10-HDA at $1 / 2 \mathrm{MIC}$, the biofilm mass decreased by $64.3 \%$ (Figure 5A). Moreover, the MTT assay indicated a substantial reduction (15.9\% to $69.2 \%)$ of the cell metabolic activity in the S. aureus mature biofilms after treatment with 10-HDA from 1/32MIC to 1/2MIC compared with the control (Figure 5B). CLSM images further confirmed the inhibition of the cell viability of mature biofilms by 10-HDA. With the increase in the 10-HDA concentration, the green fluorescence was gradually reduced and more red 
fluorescence appeared in the field of vision (Figure 5C). Collectively, these results indicate that 10-HDA could effectively eradicate the mature biofilms and reduce the bacterial viability through the mature biofilms.

A

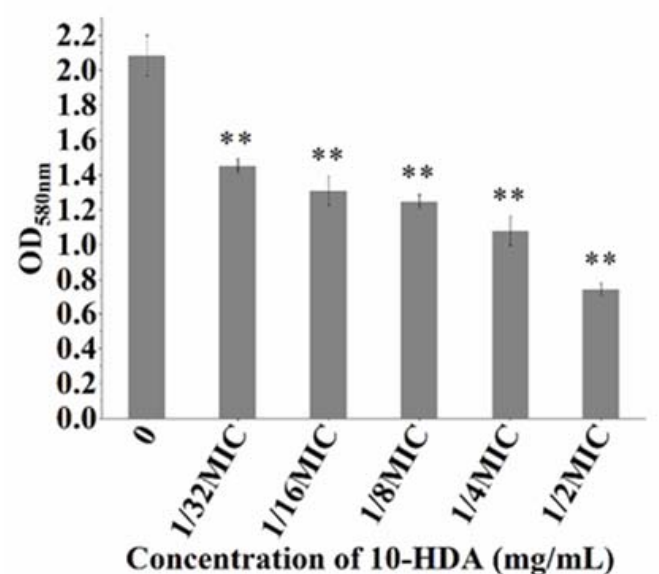

Concentration of $10-\mathrm{HDA}(\mathrm{mg} / \mathrm{mL})$
B

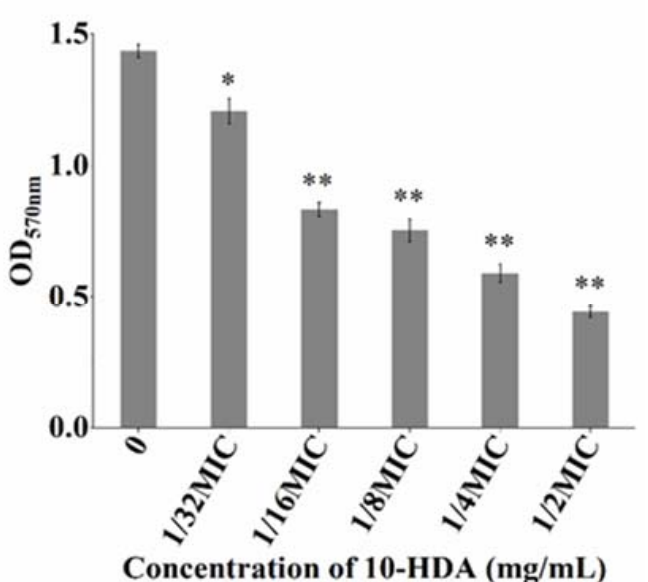

Concentration of 10-HDA $(\mathrm{mg} / \mathrm{mL})$ C
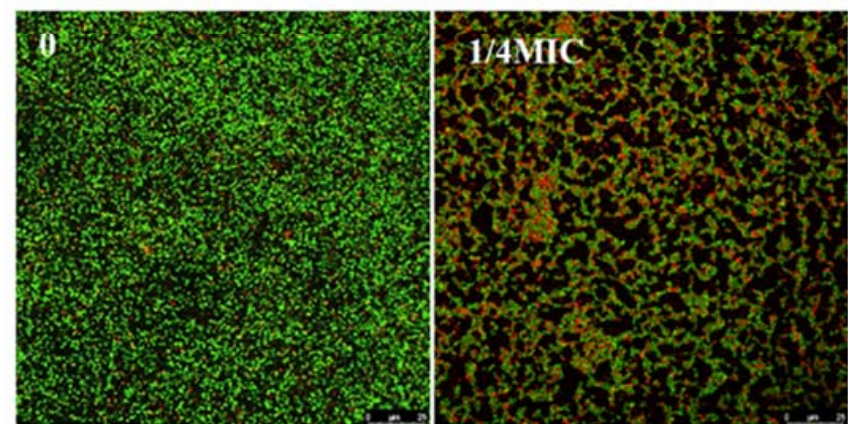

\section{1/2MIC}

Figure 5. (A) Effect of 10-HDA on S. aureus mature biofilms, as analyzed by crystal violet staining method. (B) MTT assay on the effect of 10-HDA on the cell metabolic activity in S. aureus mature biofilms. ${ }^{*} p<0.05,{ }^{* *} p<0.01$. (C) CLSM images of $S$. aureus mature biofilms. Green fluorescence: live cells; red fluorescence: dead cells.

\subsection{Effect of 10-HDA on Hemolytic Activity}

Staphylococcal hemolysins are important virulence factors contributing to bacterial invasion [35]. Alpha-hemolysin is considered the main pathogenicity factor because of its hemolytic effects. It attaches to the host red blood cells and creates pores in the cell membrane to disrupt the cellular homeostasis, eventually causing cell death [36]. In this study, the results show that the hemolytic activity of $S$. aureus treated with 10-HDA was obviously reduced when compared with the control (without 10-HDA treatment). The percent of hemolysis was dramatically reduced from $82.1 \%$ (untreated control) to $46.0 \%$, $25.0 \%, 7.2 \%, 4.2 \%$, and $4.0 \%$ after 10 -HDA treatment at $1 / 32 \mathrm{MIC}, 1 / 16 \mathrm{MIC}, 1 / 8 \mathrm{MIC}$, $1 / 4 \mathrm{MIC}$, and $1 / 2 \mathrm{MIC}$, respectively (Figure 6). These results suggest that $10-\mathrm{HDA}$ has a strong inhibitory effect on hemolysin production in $S$. aureus. 
A

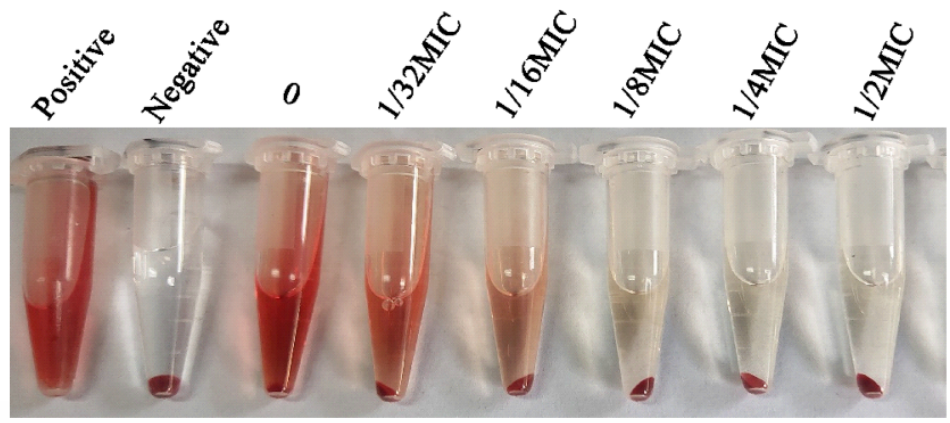

B

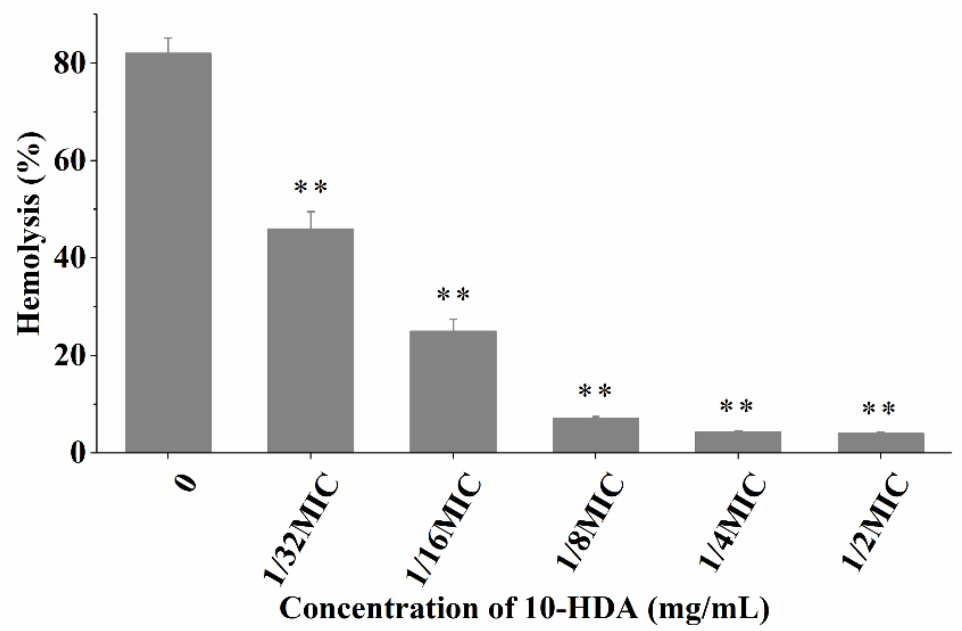

Figure 6. Efficacy of 10-HDA in inhibiting the hemolytic activity of S. aureus. (A) Qualitative and (B) quantitative analysis results are shown. ${ }^{* *} p<0.01$.

\subsection{Effect of 10-HDA on the Expression of Biofilm-and Virulence-Related Genes}

A gene expression analysis was performed to examine the anti-biofilm and antihemolysis activities of 10-HDA against $S$. aureus at the transcription level. As shown in Figure 7, when treated with 10-HDA at 1/4MIC and 1/2MIC, the expressions of sar $A$, agr $A$, and $h l a$ were significantly downregulated, and gene $i c a A$ was upregulated when compared with the control.

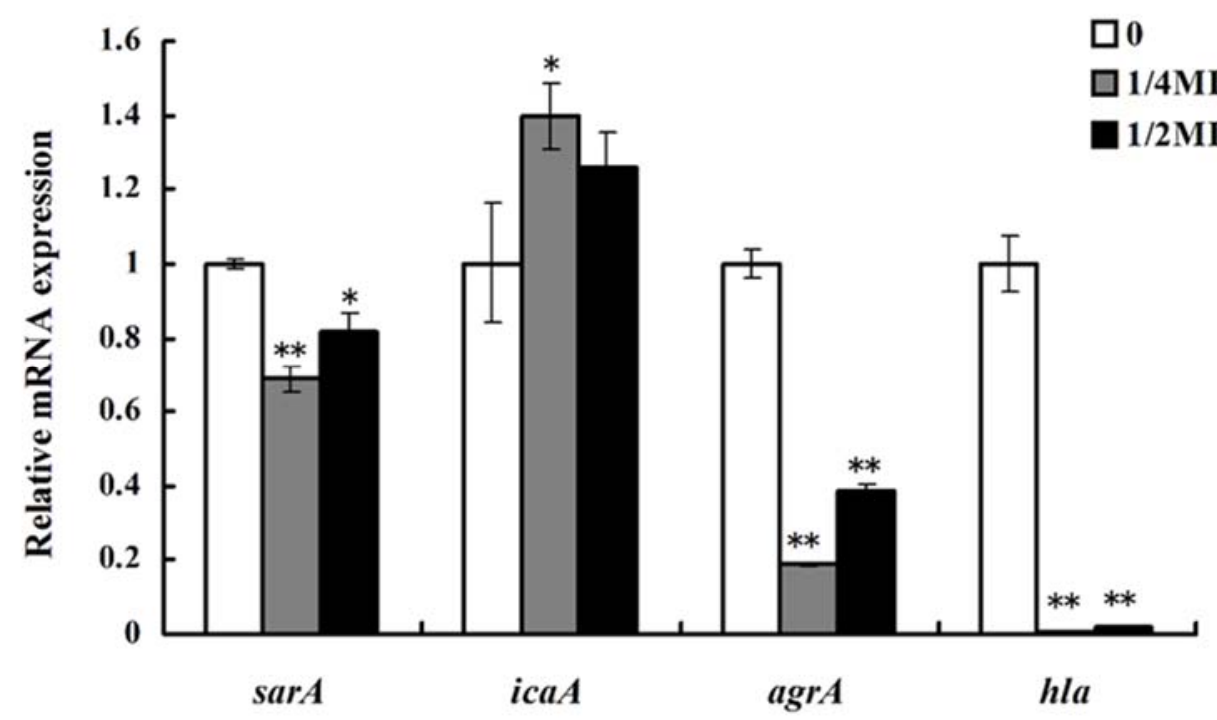

Figure 7. qRT-PCR results of 10-HDA's effect on the transcription of biofilm- and virulence-related genes. ${ }^{*} p<0.05,{ }^{* *} p<0.01$. 
The sar and agr loci are two important global regulators of biofilm formation and virulence production in $S$. aureus. sar $A$ has been shown to be involved in biofilm development, and the sar $A$ mutation decreases the ability of $S$. aureus to form biofilms [37-39]. As for agr loci, their influence on biofilm formation varies with the growth conditions, which may reflect the response of the Agr regulatory system to the external environment $[40,41]$. Moreover, the agr and sarA loci control toxin production in S. aureus. It was reported that both the agr and sar $A$ loci affected hemolysins synthesis by exerting positive impacts on alpha-hemolysin gene ( $h l a$ ) expression [42-44]. We found that sar A, agrA, and hla expressions were downregulated in 10-HAD-treated samples, indicating that sar $A$ and agr $A$ might be key regulatory factors responsible for the inhibition of biofilm and hemolytic activity. The ica operon encodes the enzymes that synthesize polysaccharide intercellular adhesin for its participation in biofilm formation [32,45]. However, our results showed that the interference of 10-HDA in biofilm formation was accompanied by the upregulation of $i c a A$. Some studies have shown that mutations of the ica locus do not reduce the ability of biofilm formation in certain $S$. aureus strains, suggesting an ica-independent pathway for biofilm formation [46-48]. Taken together, these results suggest that 10-HDA inhibits the biofilm formation and hemolytic activity of $S$. aureus by repressing the transcription of $\operatorname{sar} A$, agr $A$, and hla.

\section{Materials and Methods}

\subsection{Antimicrobial and Bacterial Strain}

10-HDA $(\geq 98 \%)$ was purchased from Shanghai Macklin Biochemical Technology Co., Ltd. (Shanghai, China). The standard strain S. aureus ATCC25923 was purchased from the China Center of Industrial Culture Collection (Beijing, China). 10-HDA was dissolved in dimethyl sulfoxide (DMSO) $(0.5 \%, v / v)$ and serially diluted to different concentrations by Tryptic Soytone Broth (TSB) liquid medium.

\subsection{Effect of 10-HDA on the Planktonic Growth and Biofilm Biomass of S. aureus}

S. aureus was cultured in TSB liquid medium for $12 \mathrm{~h}$. Then, $S$. aureus suspension $\left(1 \times 10^{6} \mathrm{CFU} / \mathrm{mL}\right)$ was incubated with $1 / 32 \mathrm{MIC}(0.07 \mathrm{mg} / \mathrm{mL}), 1 / 16 \mathrm{MIC}(0.14 \mathrm{mg} / \mathrm{mL})$, $1 / 8 \mathrm{MIC}(0.28 \mathrm{mg} / \mathrm{mL}), 1 / 4 \mathrm{MIC}(0.56 \mathrm{mg} / \mathrm{mL})$, and 1/2MIC $(1.13 \mathrm{mg} / \mathrm{mL})$ of 10-HDA in a 96-well plate at $37^{\circ} \mathrm{C}$ for $24 \mathrm{~h}$. The sample of bacterial suspension treated with DMSO was used as the control. The bacterial growth was measured by a microplate reader (Bio-Tek, Winooski, VT, USA) at $600 \mathrm{~nm}$. For the biofilm biomass analysis, the bacteria were cultured in the same way as above. After incubation, the planktonic cells were removed by washing the wells three times with PBS. The biofilms were stained with $0.5 \%$ crystal violet for $10 \mathrm{~min}$. Finally, the biofilms were dissolved in 95\% ethanol, and the absorbance at $580 \mathrm{~nm}$ was measured on a microplate reader. The percentage of inhibition of the planktonic growth or biofilm formation was calculated using the following equation [33]:

Inhibition $(\%)=\left[\left(\right.\right.$ Control $\mathrm{OD}_{600} / 580 \mathrm{~nm}-$ Treated $\left.\mathrm{OD}_{600 / 580 \mathrm{~nm}}\right) /$ Control $\left.\mathrm{OD}_{600 / 580 \mathrm{~nm}}\right] \times 100$

\subsection{SEM Analysis}

S. aureus suspension $\left(1 \times 10^{6} \mathrm{CFU} / \mathrm{mL}\right)$ was incubated with $1 / 4 \mathrm{MIC}$ and $1 / 2 \mathrm{MIC}$ of 10-HDA on glass slides $(\varphi 14 \mathrm{~mm})$ in a 24 -well plate for $24 \mathrm{~h}$ at $37{ }^{\circ} \mathrm{C}$. The samples of bacterial suspension treated with DMSO were used as the control. After incubation, the glass slides were then washed with sterile PBS, and 2.5\% (v/v) glutaraldehyde was used to fix the biofilms for $6 \mathrm{~h}$ at $4{ }^{\circ} \mathrm{C}$. Subsequently, the biofilms were dehydrated for $10 \mathrm{~min}$ using an ethanol gradient (25\%,50\%,75\%,90\%, and 100\%). Finally, the samples were coated with gold and observed under SEM (Regulus8220, Hitachi, Tokyo, Japan).

\subsection{MTT Assay}

S. aureus biofilms with $10-\mathrm{HDA}$ treatment at concentrations ranging from $1 / 32 \mathrm{MIC}$ to 1/2MIC were prepared according to the method in Section 3.2. The samples of bacterial suspension treated with DMSO were used as the control. After removing the planktonic cells, 
the cells in the biofilms were incubated with MTT $(5 \mathrm{mg} / \mathrm{mL})$ for $2 \mathrm{~h}$. During incubation, the dehydrogenase system of active cells can reduce MTT to formazan crystals. Subsequently, the MTT solution was aspirated, and the formazan solubilization solution was added to the wells to dissolve the formazan crystals in the cells. The cell viability was proportional to the concentration of formazan, which could be detected by a microplate reader at $570 \mathrm{~nm}$ [49].

\subsection{Confocal Laser Scanning Microscopy (CLSM) Observation}

S. aureus biofilms with 10-HDA treatment were prepared in a 24 -well plate according to the method in Section 3.3. After removing the planktonic cells, the biofilms were then stained with dyes (SYTO 9 and PI) according to the instructions of the LIVE/DEAD BacLight bacterial viability kit. Staining took place in the dark at room temperature for $15 \mathrm{~min}$. The biofilms were then washed with sterile water and observed under CLSM (SP8, Leica, Wetzlar, Germany).

\subsection{Determination of Extracellular Polymeric Substances Contents}

$S$. aureus biofilms with 10-HDA treatment were prepared on glass slides $(\varphi 14 \mathrm{~mm})$ in a 24-well plate. After removing the planktonic cells, the samples were sonicated with PBS and centrifuged for $20 \mathrm{~min}$ at $6000 \mathrm{r} / \mathrm{min}$. The supernatant was collected and used to measure the contents of extracellular polysaccharide, protein, and DNA. The extracellular polysaccharide content was measured by the anthrone-sulfuric acid method [50], and the extracellular protein was measured using a BCA Protein Assay Kit (Sangon, Shanghai, China). The extracellular DNA (eDNA) was extracted by the phenol-chloroform method, and the absorbance was recorded at $260 \mathrm{~nm}$.

\subsection{Effect of 10-HDA on Mature Biofilms}

S. aureus suspension $\left(1 \times 10^{6} \mathrm{CFU} / \mathrm{mL}\right)$ without 10 -HDA was cultured in 96-well or 24-well microplates at $37{ }^{\circ} \mathrm{C}$ for $48 \mathrm{~h}$ to obtain the mature biofilms. After removing the planktonic cells, the biofilms were treated with different concentrations of 10 -HDA at $37{ }^{\circ} \mathrm{C}$ for $24 \mathrm{~h}$. The samples were analyzed for biofilm biomass and cell viability as described above.

\subsection{Measurement of Hemolytic Activity}

S. aureus suspension was incubated with different concentrations of 10-HDA in a centrifuge tube for $24 \mathrm{~h}$ at $37^{\circ} \mathrm{C}$. After centrifugation $(12,000 \mathrm{rpm}, 5 \mathrm{~min}), 100 \mu \mathrm{L}$ of the supernatant was taken from each tube and incubated with $25 \mu \mathrm{L}$ of freshly washed sheep red blood cells in $875 \mu \mathrm{L}$ of PBS at $37^{\circ} \mathrm{C}$ for $1 \mathrm{~h}$. The incubation of Triton X-100 and sheep red blood cells was used as the positive control, and the incubation of PBS and sheep red blood cells served as the negative control. After centrifugation (3000 rpm, $5 \mathrm{~min}$ ), the absorbance of supernatants at $450 \mathrm{~nm}$ was examined. The percentage of hemolysis value was calculated by comparing it with the positive control (100\% hemolysis) [51].

\section{9. $q R T-P C R$}

qRT-PCR was applied to analyze the effects of 10-HDA on the transcription of genes associated with biofilm development and virulence. The gene-specific primers are listed in Table 1 , and the 16s rRNA housekeeping gene was used as an internal standard. Briefly, $S$. aureus suspension $\left(1 \times 10^{6} \mathrm{CFU} / \mathrm{mL}\right)$ with $0,1 / 4 \mathrm{MIC}$, and $1 / 2 \mathrm{MIC}$ of 10 -HDA was incubated at $37^{\circ} \mathrm{C}$ for $24 \mathrm{~h}$. Then, the biofilms were collected, and total RNA was isolated using the Bacteria Total RNA Isolation Kit (Sangon Biotech, Shanghai, China). qRT-PCR was performed using SYBR Green qPCR Mix on a real-time PCR system. Data were analyzed by the $2^{-\triangle \triangle \mathrm{CT}}$ method. 
Table 1. Primer sequences for quantitative RT-PCR.

\begin{tabular}{|c|c|}
\hline Gene & Primer \\
\hline \multirow{2}{*}{ sar $A$} & Forward 5'-CATCAGCGAAAACAAAGAGAAA-3' \\
\hline & Reverse 5'-TGTTTGCTTCAGTGATTCGTTT-3' \\
\hline \multirow[b]{2}{*}{$i c a A$} & Forward 5'-TTTCGGGTGTCTTCACTCTAT-3' \\
\hline & Reverse 5'-CGTAGTAATACTTCGTGTCCC-3' \\
\hline \multirow{2}{*}{$\operatorname{agr} A$} & Forward 5'-CAACTCGCTGACCACCTAC-3' \\
\hline & Reverse 5'-TGGAGAGAGAAACCGTGC-3' \\
\hline \multirow{2}{*}{ hla } & Forward 5'-TTGGTGCAAATGTTTC-3' \\
\hline & Reverse 5'-TCACTTTCCAGCCTACT-3' \\
\hline \multirow{2}{*}{$16 s$ rRA } & Forward 5'-ACTGGGATAACTTCGGGAAA-3' \\
\hline & Reverse 5'-CGTTGCCTTGGTAAGCC-3' \\
\hline
\end{tabular}

\subsection{Statistical Analysis}

All experiments were performed in triplicate, and the data were presented as the mean \pm SD. A significant difference between groups was determined by a one-way analysis of variance using IBM SPSS 22.0 (IBM, Armonk, NY, USA).

\section{Conclusions}

The effects of 10-HDA on the biofilms and virulence of S. aureus were evaluated for the first time. Sub-MICs of 10-HDA could effectively inhibit the formation of biofilms and eradicate the mature biofilms of $S$. aureus, as confirmed by significant reductions in biofilm biomass, cell viability, and EPS production. Moreover, the biofilm structure was visibly damaged after 10-HDA treatment. In addition, 10-HDA has a strong inhibitory effect on hemolysin production in S. aureus. qRT-PCR results indicate that 10-HDA prevents biofilm formation and hemolytic activity by repressing the transcription of the global regulators $\operatorname{sar} A$, agr $A$, and $\alpha$-hemolysin gene hla. The findings reveal that 10-HDA has remarkable inhibition effects on the biofilm formation and virulence of $S$. aureus, supporting its use as a potential natural antimicrobial agent to combat $S$. aureus.

Author Contributions: Conceptualization, K.G. and X.Y.; methodology, K.G., B.S. and X.Y.; data analysis, K.G. and B.S.; investigation, B.S. and J.D.; writing-original draft preparation, K.G.; writingreview and editing, X.Y.; funding acquisition, X.Y., P.L. and R.W. All authors have read and agreed to the published version of the manuscript.

Funding: This work was supported by the Shandong Provincial Natural Science Foundation (ZR2020MC049), the Foundation of the State Key Laboratory of Biobased Material and Green Papermaking (ZZ20190316), and the National College Students' innovation and entrepreneurship training program (201910431006).

Institutional Review Board Statement: Not applicable.

Informed Consent Statement: Not applicable.

Data Availability Statement: Not applicable.

Conflicts of Interest: The authors declare no conflict of interest.

Sample Availability: The samples are available from the authors. 


\section{References}

1. Bergin, S.P.; Holland, T.L.; Fowler, V.G., Jr.; Tong, S.Y.C. Bacteremia, sepsis, and infective endocarditis associated with Staphylococcus aureus. Curr. Top. Microbiol. 2017, 409, 263-296.

2. Krishna, S.; Miller, L.S. Host-pathogen interactions between the skin and Staphylococcus aureus. Curr. Opin. Microbiol. 2012, 15, 28-35. [CrossRef] [PubMed]

3. Omwenga, I.; Aboge, G.O.; Mitema, E.S.; Obiero, G.; Ngaywa, C.; Ngwili, N.; Wamwere, G.; Wainaina, M.; Bett, B. Staphylococcus aureus enterotoxin genes detected in milk from various livestock species in northern pastoral region of Kenya. Food Control 2019, 103, 126-132. [CrossRef]

4. Wu, S.; Huang, J.; Wu, Q.; Zhang, J.; Zhang, F.; Yang, X.; Wu, H.; Zeng, H.; Chen, M.; Ding, Y. Staphylococcus aureus isolated from retail meat and meat products in China: Incidence, antibiotic resistance and genetic diversity. Front. Microbiol. 2018, 9, 2767. [CrossRef] [PubMed]

5. Costerton, J.W.; Stewart, P.S.; Greenberg, E.P. Bacterial biofilms: A common cause of persistent infections. Science 1999, 284, 1318-1322. [CrossRef] [PubMed]

6. Schilcher, K.; Horswill, A.R. Staphylococcal biofilm development: Structure, regulation, and treatment strategies. Microbiol. Mol. Biol. 2020, 84, e00026-19. [CrossRef]

7. Di Ciccio, P.; Vergara, A.; Festino, A.; Paludi, D.; Zanardi, E.; Ghidini, S.; Ianieri, A. Biofilm formation by Staphylococcus aureus on food contact surfaces: Relationship with temperature and cell surface hydrophobicity. Food Control 2015, 50, 930-936. [CrossRef]

8. Flemming, H.C.; Wingender, J.; Szewzyk, U.; Steinberg, P.; Rice, S.A.; Kjelleberg, S. Biofilms: An emergent form of bacterial life. Nat. Rev. Microbiol. 2016, 14, 563-575. [CrossRef]

9. Flemming, H.C.; Wingender, J. The biofilm matrix. Nat. Rev. Microbiol. 2010, 8, 623-633. [CrossRef]

10. Shi, X.; Zhu, X. Biofilm formation and food safety in food industries. Trends Food Sci. Tech. 2009, 20, 407-413. [CrossRef]

11. Kong, C.; Neoh, H.; Nathan, S. Targeting Staphylococcus aureus toxins: A potential form of anti-virulence therapy. Toxins 2016, 8, 72. [CrossRef] [PubMed]

12. Surewaard, B.G.; Thanabalasuriar, A.; Zeng, Z.; Tkaczyk, C.; Cohen, T.S.; Bardoel, B.W.; Jorch, S.K.; Deppermann, C.; Wardenburg, J.B.; Davis, R.P. $\alpha$-Toxin induces platelet aggregation and liver injury during Staphylococcus aureus sepsis. Cell Host Microbe 2018, 24, 1-14. [CrossRef] [PubMed]

13. Liu, Y.; Li, R.; Xiao, X.; Wang, Z. Antibiotic adjuvants: An alternative approach to overcome multi-drug resistant Gram-negative bacteria. Crit. Rev. Microbiol. 2019, 45, 301-314. [CrossRef] [PubMed]

14. Guo, N.; Bai, X.; Shen, Y.; Zhang, T. Target-based screening for natural products against Staphylococcus aureus biofilms. Crit. Rev. Food Sci. 2021, 1-15. [CrossRef]

15. Gyawali, R.; Ibrahim, S.A. Natural products as antimicrobial agents. Food Control 2014, 46, 412-429. [CrossRef]

16. Wu, S.C.; Liu, F.; Zhu, K.; Shen, J.Z. Natural products that target virulence factors in antibiotic-resistant Staphylococcus aureus. J. Agric. Food Chem. 2019, 67, 13195-13211. [CrossRef]

17. de Campos, A.C.L.P.; Nandi, R.D.S.; Scandorieiro, S.; Gonçalves, M.C.; Reis, G.F.; Dibo, M.; Medeiros, L.P.; Panagio, L.A.; Fagan, E.P.; Kobayashi, R.K.T.; et al. Antimicrobial effect of Origanum vulgare (L.) essential oil as an alternative for conventional additives in the Minas cheese manufacture. LWT 2022, 157, 113063. [CrossRef]

18. Guo, L.; Wang, Y.; Bi, X.; Duo, K.; Sun, Q.; Yun, X.; Zhang, Y.; Fei, P.; Han, J. Antimicrobial activity and mechanism of action of the Amaranthus tricolor crude extract against Staphylococcus aureus and potential application in cooked meat. Foods 2020, 9, 359. [CrossRef]

19. Chen, Y.F.; You, M.M.; Liu, Y.C.; Shi, Y.Z.; Wang, K.; Lu, Y.Y.; Hu, F.L. Potential protective effect of trans-10-hydroxy-2-decenoic acid on the inflammation induced by lipoteichoic acid. J. Funct. Foods 2018, 45, 491-498. [CrossRef]

20. Yang, X.Y.; Yang, D.S.; Wang, J.M.; Li, C.Y.; Lei, K.F.; Chen, X.F.; Shen, N.H.; Jin, L.Q.; Wang, J.G. 10-Hydroxy-2-decenoic acid from royal jelly: A potential medicine for RA. J. Ethnopharmacol 2010, 128, 314-321. [CrossRef]

21. Lin, X.M.; Liu, S.B.; Luo, Y.H.; Xu, W.T.; Zhang, Y.; Zhang, T.; Xue, H.; Zuo, W.B.; Li, Y.N.; Lu, B.X. 10-HDA induces ROS-mediated apoptosis in A549 human lung cancer cells by regulating the MAPK, STAT3, NF- $\mathrm{B}$, and TGF- $\beta 1$ signaling pathways. Biomed. Res. Int. 2020, 2020, 3042636. [CrossRef]

22. Nakaya, M.; Onda, H.; Sasaki, K.; Yukiyoshi, A.; Tachibana, H.; Yamada, K. Effect of royal jelly on bisphenol A-induced proliferation of human breast cancer cells. Biosci. Biotech. Bioch. 2007, 71, 253-255. [CrossRef] [PubMed]

23. Townsend, G.F.; Morgan, J.F.; Tolnai, S.; Hazlett, B.; Morton, H.J.; Shuel, R. Studies on the in vitro antitumor activity of fatty acids: I. 10-hydroxy-2-decenoic acid from royal jelly. Cancer Res. 1960, 20, 503-510. [PubMed]

24. Cornara, L.; Biagi, M.; Xiao, J.; Burlando, B. Therapeutic properties of bioactive compounds from different honeybee products. Front. Microbiol. 2017, 8, 412. [CrossRef] [PubMed]

25. Li, X.A.; Huang, C.; Xue, Y. Contribution of lipids in honeybee (Apis mellifera) royal jelly to health. J. Med. Food 2013, 16, 96-102. [CrossRef]

26. Honda, Y.; Fujita, Y.; Maruyama, H.; Araki, Y.; Ichihara, K.; Sato, A.; Kojima, T.; Tanaka, M.; Nozawa, Y.; Ito, M. Lifespan-extending effects of royal jelly and its related substances on the nematode Caenorhabditis elegans. PLoS ONE 2011, 6, e23527. [CrossRef]

27. Li, J.L.; Yang, X.H.; Wang, T.F.; Hao, Z.C.; Dai, K.; Wang, R.M. Studies on antibacterial mechanism of 10-HDA against Staphylococcus aureus. J. Chin. Institute Food Sci. Technol. 2014, 14, 73-79. 
28. Opperman, T.J.; Kwasny, S.M.; Williams, J.D.; Khan, A.R.; Peet, N.P.; Moir, D.T.; Bowlin, T.L. Aryl rhodanines specifically inhibit staphylococcal and enterococcal biofilm formation. Antimicrob. Agents Chemother. 2009, 53, 4357-4367. [CrossRef]

29. Alpkvist, E.; Picioreanu, C.; van Loosdrecht, M.C.; Heyden, A. Three-dimensional biofilm model with individual cells and continuum EPS matrix. Biotechnol. Bioeng. 2006, 94, 961-979. [CrossRef]

30. Lee, S.; Cappato, L.; Corassin, C.; Cruz, A.; Oliveira, C. Effect of peracetic acid on biofilms formed by Staphylococcus aureus and Listeria monocytogenes isolated from dairy plants. J. Dairy Sci. 2016, 99, 2384-2390. [CrossRef]

31. Kang, J.; Li, Q.; Liu, L.; Jin, W.; Wang, J.; Sun, Y. The specific effect of gallic acid on Escherichia coli biofilm formation by regulating pgaABCD genes expression. Appl. Microbiol. Biotechnol. 2018, 102, 1837-1846. [CrossRef] [PubMed]

32. Liu, M.; Wu, X.; Li, J.; Liu, L.; Zhang, R.; Shao, D.; Du, X. The specific anti-biofilm effect of gallic acid on Staphylococcus aureus by regulating the expression of the ica operon. Food Control 2017, 73, 613-618. [CrossRef]

33. Bai, J.R.; Zhong, K.; Wu, Y.-P.; Elena, G.; Gao, H. Antibiofilm activity of shikimic acid against Staphylococcus aureus. Food Control 2019, 95, 327-333. [CrossRef]

34. Sauer, K.; Rickard, A.H.; Davies, D.G. Biofilms and biocomplexity. Microbe 2007, 2, 347. [CrossRef]

35. Wilson, B.A.; Winkler, M.; Ho, B.T. Bacterial Pathogenesis: A Molecular Approach, 4th ed.; ASM Press: Washington, DC, USA, 2020.

36. Menestrina, G.; Dalla Serra, M.; Comai, M.; Coraiola, M.; Viero, G.; Werner, S.; Colin, D.; Monteil, H.; Prevost, G. Ion channels and bacterial infection: The case of $\beta$-barrel pore-forming protein toxins of Staphylococcus aureus. FEBS Lett. 2003, 552, 54-60. [CrossRef]

37. Beenken, K.E.; Blevins, J.S.; Smeltzer, M.S. Mutation of sarA in Staphylococcus aureus limits biofilm formation. Infect. Immun. 2003, 71, 4206-4211. [CrossRef]

38. Valle, J.; Toledo-Arana, A.; Berasain, C.; Ghigo, J.M.; Amorena, B.; Penadés, J.R.; Lasa, I. SarA and not $\sigma B$ is essential for biofilm development by Staphylococcus aureus. Mol. Microbiol. 2003, 48, 1075-1087. [CrossRef]

39. Valliammai, A.; Selvaraj, A.; Yuvashree, U.; Aravindraja, C.; Karutha Pandian, S. sarA-dependent antibiofilm activity of thymol enhances the antibacterial efficacy of rifampicin against Staphylococcus aureus. Front. Microbiol. 2020, 11, 1744. [CrossRef]

40. Lee, H.S.; Song, H.-S.; Lee, H.-J.; Kim, S.H.; Suh, M.J.; Cho, J.Y.; Ham, S.; Kim, Y.-G.; Joo, H.-S.; Kim, W. Comparative study of the difference in behavior of the accessory gene regulator (Agr) in USA300 and USA400 community-associated methicillin-resistant Staphylococcus aureus (CA-MRSA). J. Microbiol. Biotech. 2021, 31, 1060-1068. [CrossRef]

41. Yarwood, J.M.; Bartels, D.J.; Volper, E.M.; Greenberg, E.P. Quorum sensing in Staphylococcus aureus biofilms. J. Bacteriol. 2004, 186, 1838-1850. [CrossRef]

42. Goerke, C.; Fluckiger, U.; Steinhuber, A.; Zimmerli, W.; Wolz, C. Impact of the regulatory loci agr, sarA and sae of Staphylococcus aureus on the induction of $\alpha$-toxin during device-related infection resolved by direct quantitative transcript analysis Mol. Microbiol. 2001, 40, 1439-1447. [CrossRef] [PubMed]

43. Venkatasubramaniam, A.; Kanipakala, T.; Ganjbaksh, N.; Mehr, R.; Mukherjee, I.; Krishnan, S.; Bae, T.; Aman, M.J.; Adhikari, R.P. A critical role for HlgA in Staphylococcus aureus pathogenesis revealed by a switch in the SaeRS two-component regulatory system. Toxins 2018, 10, 377. [CrossRef] [PubMed]

44. Xiong, Y.Q.; Willard, J.; Yeaman, M.R.; Cheung, A.L.; Bayer, A.S. Regulation of Staphylococcus aureus $\alpha$-toxin gene (hla) expression by agr, sarA and sae in vitro and in experimental infective endocarditis. J. Inf. Dis. 2006, 194, 1267-1275. [CrossRef] [PubMed]

45. Arciola, C.R.; Campoccia, D.; Ravaioli, S.; Montanaro, L. Polysaccharide intercellular adhesin in biofilm: Structural and regulatory aspects. Front. Cell. Infection Mi. 2015, 5, 7. [CrossRef]

46. Beenken, K.E.; Dunman, P.M.; McAleese, F.; Macapagal, D.; Murphy, E.; Projan, S.J.; Blevins, J.S.; Smeltzer, M.S. Global gene expression in Staphylococcus aureus biofilms. J. Bacteriol. 2004, 186, 4665-4684. [CrossRef]

47. Rode, T.M.; Langsrud, S.; Holck, A.; Møretrø, T. Different patterns of biofilm formation in Staphylococcus aureus under food-related stress conditions. Int. J. Food Microbiol. 2007, 116, 372-383. [CrossRef]

48. Figueiredo, A.M.S.; Ferreira, F.A.; Beltrame, C.O.; Côrtes, M.F. The role of biofilms in persistent infections and factors involved in ica-independent biofilm development and gene regulation in Staphylococcus aureus. Crit. Rev. Microbiol. 2017, 43, 602-620. [CrossRef]

49. Schillaci, D.; Arizza, V.; Dayton, T.; Camarda, L.; Stefano, V.D. In vitro anti-biofilm activity of Boswellia spp. oleogum resin essential oils. Lett. Appl. Microbiol. 2008, 47, 433-438. [CrossRef]

50. Zhang, G.; Lu, M.; Liu, R.; Tian, Y.; Vu, V.H.; Li, Y.; Liu, B.; Kushmaro, A.; Li, Y.; Sun, Q. Inhibition of Streptococcus mutans biofilm formation and virulence by Lactobacillus plantarum K41 isolated from traditional Sichuan pickles. Front. Microbiol. 2020, 11, 774. [CrossRef]

51. Tang, F.; Li, L.; Meng, X.M.; Li, B.; Wang, C.Q.; Wang, S.Q.; Wang, T.L.; Tian, Y.M. Inhibition of alpha-hemolysin expression by resveratrol attenuates Staphylococcus aureus virulence. Microb. Pathogenesis 2019, 127, 85-90. [CrossRef] 